\title{
Anion Transport and 2,3-Diphosphoglycerate in Cystic Fibrosis Red Blood Cells
}

\author{
A. G. R. V. BERGHOUT AND S. W. BENDER \\ Max-Planck-Institut fuer Biophysik [A.G.R.V.B.] and Zentrum der Kinderheilkunde, J. W. Goethe Universitaet \\ [S.W.B.], Frankfurt/Main, Federal Republic of Germany.
}

\begin{abstract}
Summary
The monovalent and divalent anion transport in red blood cells from patients with cystic fibrosis and controls is not significantly different. The protein pattern of the erythrocyte membrane, as seen by sodium dodecyl sulfate-polyacrylamide gel electropherograms, is similar in cystic fibrosis and control red blood cells. The 2,3-diphosphoglycerate content of the investigated cystic fibrosis red blood cells is normal.
\end{abstract}

\section{Abbreviations}

DIDS, 4,4'-diisothiocyanate-1,2-diphenylethane-2,2' -disulfonic acid

CF, cystic fibrosis

2,3-DPG, 2,3-diphosphoglycerate

SDS, sodium dodecyl sulfate

The molecular defect in cystic fibrosis is still unknown. It is an autosomal, recessive genetic disease characterized by an impairment of the exocrine gland function that leads to serious complications in the pulmonary and digestive tract (32). One of the diagnostic features is an elevation of the sodium and chloride concentration in sweat, collected after stimulation with pilocarpin and a weak galvanic current.

Many experimental approaches have been used to elucidate the primary defect in this disease $(6,22,32)$. The easy availability of erythrocytes and their well characterized properties have stimulated many studies in cation transport across the cystic fibrosis red blood cell membrane which will be summarized in the discussion $(1,4,7,8,12-14,20,23,24)$. Critical review of the conflicting data leads to the conclusion that monovalent and divalent cation transport across the erythrocyte membrane of cystic fibrosis patients and healthy control subjects is not different.

Recently, it has been suggested that a generalized defect in anion or chloride permeability is involved in cystic fibrosis. Quinton's work on isolated perfused sweat gland ducts of patients with cystic fibrosis points to an inhibition of chloride transport across the ductal epithelium (27-29). He postulates that in the patients, in contrast to the controls, chloride cannot be reabsorbed from the ductal sweat in exchange for another anion, such as bicarbonate. The sodium reabsorption is also inhibited, supposedly because of the absence of an electrogenic chloride transport. This leads to an elevation of both sodium and chloride concentration in secreted sweat. Bicarbonate secretion in the

Received November 25, 1983; accepted March 19, 1984

Address correspondence to Alexander Berghout, Max-Planck-Institut fuer Biophysik, H. Hoffmannstrasse 7, 6000 Frankfurt/Main 71, Federal Republic of Germany.

A part of this work was supported by Grant Be 575/3-2 from the Deutsche Forschungsgemeinschaft. pancreas of patients with cystic fibrosis is also inhibited according to Gaskin et al. (10).

Anion transport across the membrane of the human red blood cell is well documented $(3,5,9,17,25,31,35)$. It is mediated by the so-called band 3 protein and can be inhibited by stilbene disulfonates very specifically. In various other types of cells, a saturable anion transport can be found that can also be inhibited by stilbene disulfonates. For example, in Ehrlich ascites tumor cells (21) and rabbit ileum (19), sulfate transport can be strongly inhibited by these compounds, whereas chloride transport is almost unaffected. Active chloride transport in the amphibian cornea is inhibited on both the aqueous and tear side of the cells by DIDS (2). However, these transport systems have not yet been characterized in so much detail that any conclusions can be drawn about the analogy to the anion transporter of the human red blood cell. It has been shown by immunological methods that in various nucleated somatic cells, including human fibroblasts, lung cells, and squamous epithelial mouth cells, there are polypeptides present that have antigenic determinants in common with erythrocyte band 3 (16). Therefore, although it is not yet clear if there exists a ubiquitous protein for the transport of anions across the cell membrane, like the $\mathrm{Na} / \mathrm{K}$-ATPase for the transport of cations, there are indications that band 3-like proteins are also present in cell types other than the erythrocyte. So far as the sweat gland is concerned, it should be noted, however, that no effect on sweat secretion and sodium reabsorption is seen when furosemide, also an inhibitor of anion transport in erythrocytes, is applied on both the luminal or contraluminal side of isolated, perfused single human sweat glands (26).

This is the first report on anion transport of the red blood cell in cystic fibrosis. We realize that the study of anion transport in red blood cells in a genetic disease which manifests itself primarily in secretory cells is of disputable significance. However, such investigation has become desirable in view of the hypothesis mentioned above.

\section{MATERIALS AND METHODS}

The patients with cystic fibrosis were attending the outpatient clinic and were not selected. Most patients received doxycyclin, acetylcysteine, pancreatic extracts, and vitamins. Care was taken that no known inhibitors of anion transport (i.e. salicylates, furosemide) were used. Freshly drawn heparinized venous blood from controls $(\mathrm{K})$ and ambulatory $\mathrm{CF}$ patients was washed three times in $130 \mathrm{mM} \mathrm{NaCl}, 1 \mathrm{mM} \mathrm{Na} \mathrm{SO}_{4}, 20 \mathrm{mM}$ EDTA (standard medium), $\mathrm{pH} 7.4,0^{\circ} \mathrm{C}$. The red cells were then equilibrated in this medium with ${ }^{36} \mathrm{Cl}$ for at least $30 \mathrm{~min}$ at $0^{\circ} \mathrm{C}$. and samples were taken for the determination of hematocrit, wet and dry weight, and the ratio of intracellular to extracellular chloride concentration (Donnan ratio). The ${ }^{36} \mathrm{Cl}$ efflux was initiated by resuspension of the sedimented cells at a hematocrit of about $0.5 \%$ in standard medium, $\mathrm{pH} 7.4,0^{\circ} \mathrm{C}$. Supernatant was taken 
by the filter technique of Dalmark (5) at suitable time intervals and the radioactivity was determined in aliquots thereof.

Resealed red cell ghosts were prepared as described by Schwoch and Passow (30), $24 \mathrm{~h}$ after blood sampling and storage at $4^{\circ} \mathrm{C}$ in standard medium. A hemolysis ratio of 1 volume of a $50 \%$ cell suspension in isotonic $\mathrm{NaCl}$ plus 25 volumes of hemolyzing medium $\left(4 \mathrm{mM} \mathrm{MgSO}_{4}, 0.5 \mathrm{mM}\right.$ acetic acid, $0^{\circ} \mathrm{C}$.) was used. Ghost volumina were determined by means of a Coulter Counter and by determination of the radiosulfate, entrapped by the ghosts.

Rate constants for anion efflux were calculated by fitting a single exponential to the data points by means of a nonlinear curve-fitting procedure. The anion efflux in red blood cells was calculated from the equation: $J=k \times r \times C \times f\left(\mathrm{mM} \cdot \mathrm{min}^{-1} \cdot \mathrm{kg}\right.$ cell solids ${ }^{-1}$ ), where $k=$ the rate constant in $\min ^{-1}, r=$ the ratio of the chloride concentration inside/outside (Donnan ratio), $C$ $=$ the chloride concentration in $\mathrm{mM} /$ liter, and $f=$ the ratio $\mathrm{kg}$ cell water $/ \mathrm{kg}$ cell solids. The flux for red cell ghosts was calculated from the equation: $J=k \times M C V / A \times C_{i}\left(\mathrm{M} \cdot \mathrm{min}^{-1} \cdot \mathrm{cm}^{-2}\right)$, where $k=$ the rate constant in $\min ^{-1}, M C V=$ the average ghost volume in femtoliters, $A=$ the surface area of a human red blood cell $\left[1.42 \times 10^{-6} \mathrm{~cm}^{2} ;(18,34)\right]$ and $C_{i}=$ the chloride concentration in $\mathrm{M} \cdot \mathrm{cm}^{-3}$. The flux can also be expressed as $\mathrm{M} \cdot \mathrm{min}^{-1} \cdot \mathrm{kg}^{-1}$ cell solids by multiplying the flux (in $\mathrm{M} \cdot \mathrm{min}^{-1} \cdot \mathrm{cm}^{-2}$ ) by the factor $4.4 \times 10^{7} \mathrm{~cm}^{2}$, which is the surface area of $3.1 \times 10^{13}$ cells $(=1$ $\mathrm{kg}$ cell solids).

Spectrophotometric determinations of 2,3-DPG were carried out immediately after blood sampling by means of a test kit purchased from Boehringer.

$5 \%$ Polyacrylamide gel electrophoresis with SDS was performed after preparing white ghosts by washing the red cells at $0^{\circ} \mathrm{C}$ with buffer, $\mathrm{pH} 7.4$, containing $0.1 \%$ saponin and solubilizing the pellet in $5 \% \mathrm{SDS}$ and dithiothreitol for $3 \mathrm{~min}$ at $100^{\circ} \mathrm{C}$.

\section{RESULTS}

Figure 1 shows the semilogarithmic plot of ${ }^{36} \mathrm{Cl}$ effluc at $0^{\circ} \mathrm{C}$ and $\mathrm{pH} 7.4$ in a patient with cystic fibrosis and a control subject. With the filter technique we used, one can only measure the chloride exchange at low temperatures. The isotope efflux is so fast that it reaches equilibrium in about $1 \mathrm{~min}$ at $0^{\circ} \mathrm{C}$. The rate constant can be calculated from the slope of this plot.

Table 1 shows the chloride equilibrium efflux in red blood cells obtained from four healthy donors and 11 patients with

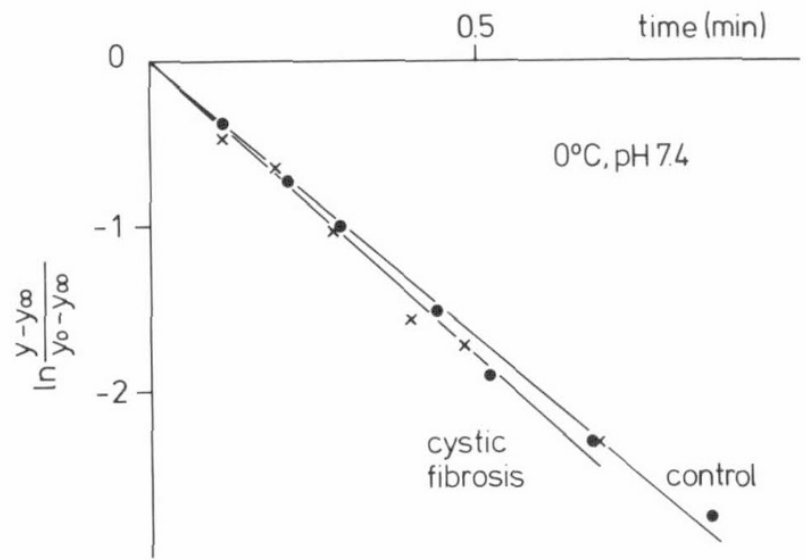

Fig. 1. One example of chloride equilibrium exchange in erythrocytes of a healthy control subject $(-)$ and a patient with cystic fibrosis $(\times)$ at $0^{\circ} \mathrm{C}, \mathrm{pH}$ 7.4. Ordinate, $Y, Y_{0}$, and $Y_{\infty}$ represent, respectively, the radioactivity in the supernatant at times $t, t=0$ and $t=\infty$. Abscissa, time in minutes. The rate constant can be calculated from the slope of the straight line through the data points, according to the equation: $\ln (Y-$ $\left.Y_{\infty}\right) /\left(\mathrm{Y}_{0}-Y_{\infty}\right)=-k \times t$, where $k$ represents the rate constant for chloride efflux in $\min ^{-1}$ and $t$ represents the time in minutes.
Table 1. Chloride equilibrium efflux in red blood cells*

\begin{tabular}{|c|c|c|c|c|c|}
\hline Subject & $k_{\mathrm{Cl}}$ & $n$ & $r$ & $f$ & $\begin{array}{l}\text { Flux } \\
\left(\mathrm{mM} \cdot \mathrm{min}^{-1} \cdot \mathrm{kg}^{-1}\right. \\
\text { cell solids })\end{array}$ \\
\hline \multicolumn{6}{|l|}{ Controls } \\
\hline Kl & $3.423 \pm 0.507$ & 4 & 0.63 & 1.42 & 398 \\
\hline K2 & $4.207 \pm 0.003$ & 2 & 0.78 & 1.41 & 602 \\
\hline $\mathrm{K} 3$ & $3.287 \pm 0.221$ & 2 & 0.77 & 1.39 & 457 \\
\hline $\mathrm{K} 4$ & $3.633 \pm 0.128$ & 2 & 0.47 & 1.44 & 320 \\
\hline Mean flux & & & & & $444 \pm 60$ \\
\hline \multicolumn{6}{|l|}{ Cystic fibrosis } \\
\hline $\mathrm{CF} 1$ & $2.432 \pm 0.338$ & 3 & 0.86 & 1.92 & 522 \\
\hline $\mathrm{CF} 2$ & $2.566 \pm 0.084$ & 3 & 0.87 & 2.04 & 592 \\
\hline $\mathrm{CF} 3$ & $2.574 \pm 0.158$ & 3 & 0.85 & 2.26 & 643 \\
\hline CF4 & $2.717 \pm 0.251$ & 5 & 0.48 & 1.88 & 319 \\
\hline CF5 & $3.302 \pm 0.012$ & 3 & 0.61 & 2.34 & 613 \\
\hline CF6 & $3.494 \pm 0.244$ & 3 & 0.72 & 2.26 & 739 \\
\hline CF7 & $3.950 \pm 0.043$ & 3 & 0.89 & 2.07 & 946 \\
\hline CF8 & $4.026 \pm 0.351$ & 5 & 0.37 & 1.69 & 327 \\
\hline CF9 & $3.893 \pm 0.075$ & 3 & 0.79 & 1.93 & 772 \\
\hline CF 10 & $3.369 \pm 0.158$ & 5 & 0.55 & 1.59 & 383 \\
\hline CF11 & $3.081 \pm 0.198$ & 5 & 0.40 & 1.81 & 290 \\
\hline Mean flux & & & & & $559 \pm 64$ \\
\hline
\end{tabular}

* The chloride equilibrium efflux was measured in standard medium at $0^{\circ} \mathrm{C} . k_{\mathrm{Cl}}=$ rate constant $\left(\mathrm{min}^{-1}\right)$, mean \pm SEM. $n$, Number of experiments; $r$, Donnan ratio; $f, \mathrm{~kg}$ cell water $/ \mathrm{kg}$ cell solids.

Table 2. 2,3-DPG content of red blood cells*

\begin{tabular}{cc}
\hline Subject & $\begin{array}{c}2,3-\mathrm{DPG} \\
(\mathrm{mM} / \text { liter red cells })\end{array}$ \\
Controls & 5.29 \\
$\mathrm{~K} 1$ & 5.67 \\
$\mathrm{~K} 2$ & 6.19 \\
$\mathrm{~K} 3$ & 5.16 \\
$\mathrm{~K} 4$ & 5.42 \\
Cystic fibrosis & \\
CF4 & 5.72 \\
CF8 & 5.17 \\
CF10 & 5.15 \\
CF11 & 5.24
\end{tabular}

* Note that the chloride and sulfate fluxes in erythrocyte ghosts from the same subjects are presented in Tables 3 and 4.

cystic fibrosis. The mean flux amounts to 444 and $559 \mathrm{mM}$. $\mathrm{min}^{-1} \cdot \mathrm{kg}^{-1}$ cell solids, respectively. This difference is not statistically significant (Student's $t$ test; $p \leqslant 0.15$ ).

Pulmonary complications in cystic fibrosis patients are common. The resulting hypoxemia raises the 2,3-DPG content of the red cell. The oxygen saturation curve of hemoglobin shifts to the left. 2,3-DPG is the most important nonpenetrating anion in the red cell after hemoglobin (11). The other organic phosphates, mainly ATP, are less important nonpenetrating anions. Nonpenetrating anions decrease the Donnan ratio and concomitantly the anion efflux (see "Material and Methods"). This lead us to measure the 2,3-DPG content in the erythrocytes of four patients with cystic fibrosis who had a relatively slow chloride efflux. Table 2 shows that the 2,3-DPG levels in the freshly drawn red blood cells of controls and patients with cystic fibrosis have normal values.

Secondly, we also measured the chloride efflux in "pink" red blood cell ghosts to avoid any influence of impermeant charged solutes on the determination of the anion flux. Red blood cell ghosts lack hemoglobin and other charged constituents, so the Donnan ratio is one (9). Table 3 shows that the mean flux is 9.7 and $7.7 \mathrm{nM} \cdot \mathrm{min}^{-1} \cdot \mathrm{cm}^{-2}$ in erythrocyte ghosts of controls and 
Table 3. Chloride equilibrium efflux in ghosts*

\begin{tabular}{lccc}
\hline Subject & $\begin{array}{c}k_{\mathrm{Cl}} \\
\left(\mathrm{min}^{-1}\right)\end{array}$ & $\begin{array}{c}M C V \\
(\mathrm{fl})\end{array}$ & $\begin{array}{c}\text { Flux } \\
\left(\mathrm{M} \cdot \mathrm{min}^{-1} \cdot \mathrm{cm}^{-2}\right) \times 10^{10}\end{array}$ \\
\hline Controls & & & 100 \\
K1 & 2.006 & 54.2 & 125 \\
& 2.510 & & 95 \\
& 2.541 & 40.8 & 87 \\
K2 & 2.317 & & 90 \\
& 2.704 & 36.2 & 98 \\
K3 & 2.969 & & 91 \\
& 2.267 & 44.0 & 79 \\
K4 & 1.971 & & 109 \\
& 2.522 & 47.2 & 104 \\
Mean flux & 3.310 & & $97 \pm 5$ \\
Cystic fibrosis & & & 55 \\
CF4 & 1.312 & 45.6 & 46 \\
& 1.107 & & 40 \\
CF8 & 1.078 & 40.4 & 47 \\
& 1.269 & & 111 \\
CF10 & 1.997 & 60.5 & 141 \\
& 2.546 & & 88 \\
CF11 & 1.874 & 51.5 & 87 \\
& 1.849 & & $77 \pm 19$ \\
Mean flux & & &
\end{tabular}

* The chloride equilibrium efflux was measured in standard medium at $0^{\circ} \mathrm{C} . k_{\mathrm{Cl}}$, rate constant $\left(\mathrm{min}^{-1}\right)$.

patients with cystic fibrosis, respectively. This difference is also not statistically significant (Student's $t$ test; $p \leqslant 0.15$ ).

As an example for the transport of divalent anions, we examined the sulfate efflux in erythrocyte ghosts that can easily be measured at $37^{\circ} \mathrm{C}$ since it is much slower than that of chloride. Equilibrium is not reached before $90 \mathrm{~min}$ under our conditions. Table 4 shows the sulfate fluxes measured in red blood cell ghosts at $37^{\circ} \mathrm{C}$ and $\mathrm{pH} 7.4$. No difference is found for the transport of this divalent anion across the membrane of control and cystic fibrosis erythrocytes.

$\mathrm{H}_{2}$ DIDS is a very specific inhibitor of anion transport in the human erythrocyte $(17,25)$. This inhibitor binds covalently in a 1:1 ratio to the band 3 monomer. The $\mathrm{H}_{2}$ DIDS-binding site and the mechanism by which $\mathrm{H}_{2}$ DIDS binds to this site are well documented (25). We found $98 \%$ inhibition of chloride and sulfate efflux in both control and cystic fibrosis erythrocytes by $\mathrm{H}_{2}$ DIDS. The inhibitor concentration in the flux medium was $25 \mu \mathrm{M}$. This is also an indication that the function of the anion transport protein in cystic fibrosis is normal.

\section{DISCUSSION}

Anion exchange in the red blood cell is mediated by an intrinsic membrane protein, the 'band 3' protein, so-called according to its localization in polyacrylamide gels (31). It accounts for about $25 \%$ of the total protein of the membrane. It is a $95-\mathrm{kD}$ polypeptide that mediates the transport of both mono- and divalent inorganic anions as well as organic anions (17). Parts of the amino acid sequence of this protein are now known $(3,15)$. It is an integral membrane protein and crosses the membrane at least seven times. Each erythrocyte contains about 1 million monomers of the anion transporter. Each monomer forms a functioning unit. Band 3 appears in a rather broad band on polyacrylamide gel electropherograms since the polypeptide is glycosylated with different oligosaccharides. Other minor polypeptides of similar molecular weight migrate in this region as well (31). Figure 2 shows the polyacrylamide gel electropherograms of the red blood cell membrane proteins in a healthy subject and three patients with cystic fibrosis. No abnormal bands can be detected, reconfirming the findings of McEvoy et al. $(8,23)$.

Much information on the function of the anion transport
Table 4. Sulfate equilibrium exchange in ghosts*

\begin{tabular}{lccc}
\hline \multicolumn{1}{c}{ Subject } & $\begin{array}{c}k_{\mathrm{SO}_{4}} \\
\left(\times 10^{-2}\right)\end{array}$ & $M C V$ & $\begin{array}{c}\text { Flux } \\
\left(\mathrm{M} \cdot \mathrm{min}^{-1} \cdot \mathrm{cm}^{-2}\right) \times 10^{14}\end{array}$ \\
\hline Controls & & & \\
K1 & 1.49 & 47.5 & 50 \\
K2 & 1.44 & 36.2 & 37 \\
K3 & 1.21 & 44.0 & 38 \\
K4 & 1.47 & 47.2 & 49 \\
Mean flux & & & $44 \pm 4$ \\
Cystic fibrosis & & & \\
CF4 & 1.25 & 45.6 & 40 \\
CF8 & 1.31 & 40.4 & 37 \\
CF10 & 1.34 & 60.5 & 57 \\
CF11 & 1.21 & 51.5 & 44 \\
Mean flux & & & $45 \pm 4$ \\
\hline
\end{tabular}

The sulfate equilibrium efflux was measured in standard medium at $37^{\circ} \mathrm{C} . k_{\mathrm{SO}_{4}}=$ rate constant $\left(\mathrm{min}^{-1}\right)$ and $M C V=$ mean ghost volume (f1).
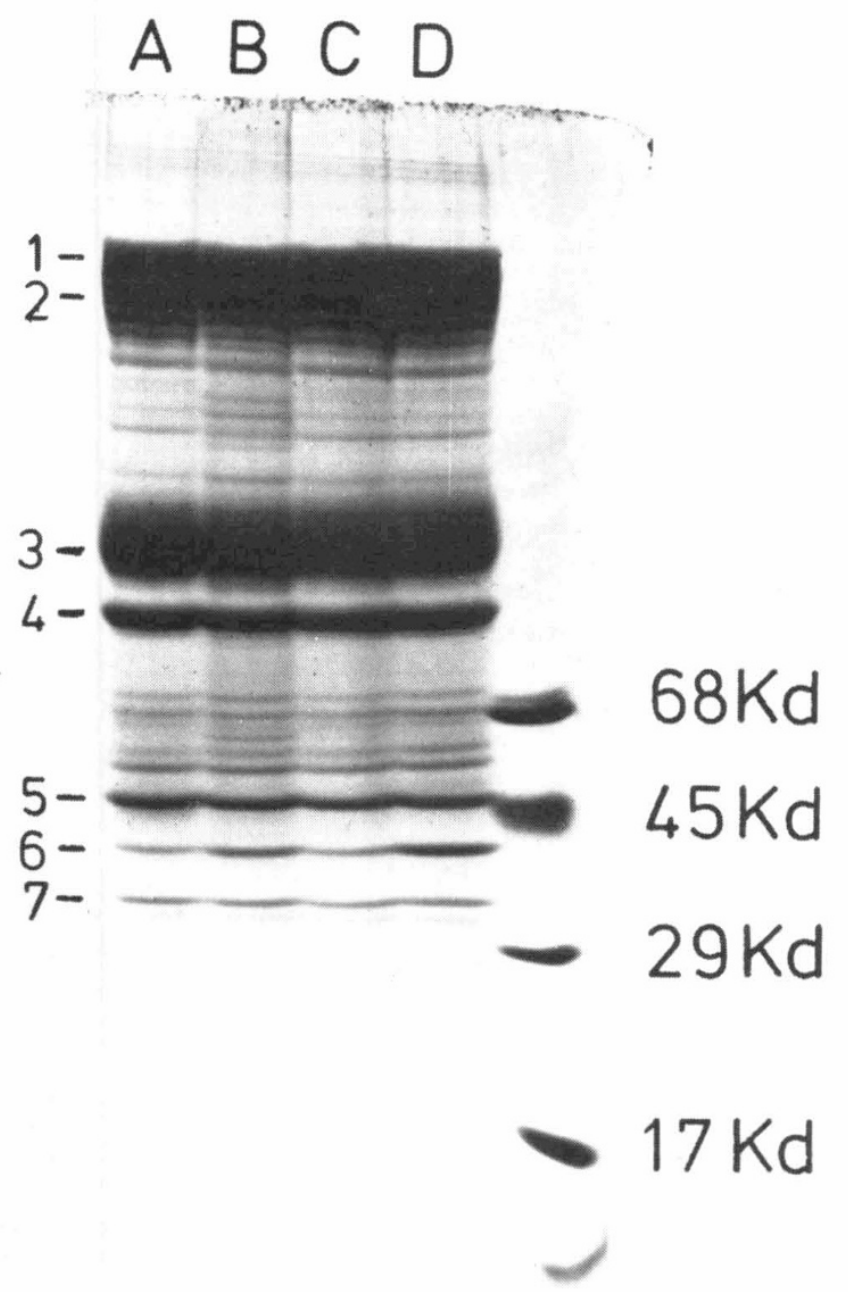

Fig. 2. SDS-polyacrylamide gel electropherograms of a healthy subject $(A)$ and three patients with cystic fibrosis $(B-D)$. The outer lane on the right contains proteins of known molecular weight as indicated in kilodaltons. The enumeration of the protein bands of the erythrocyte membrane according to Steck (31) is presented on the left. The apparent accessory bands in lane $B$ are caused by mild proteolysis (observed in about $50 \%$ of the gels).

protein of the red blood cell membrane has now accumulated $(3,5,9,17,35)$. This protein exchanges chloride for bicarbonate and vice versa (Hamburger shift). The capacity of the blood in transporting carbon dioxide from the tissues to the lungs is thus 
increased because $80 \%$ of the carbon dioxide is transported as bicarbonate ions (35). Inhibition of this system (e.g. by salicylate poisoning) causes an increase in the $\mathrm{PCO}_{2}$ of the blood leading to hyperventilation. Hypercapnia is not found in cystic fibrosis unless pulmonary complications are present. From this, one would not expect a serious impairment of the anion transport in red blood cells of cystic fibrosis patients.

Studies on monovalent and divalent cation transport in cystic fibrosis red blood cells have often led to contradictory results. In the following, we summarize briefly these data beginning with the monovalent cations.

Balfe et al. (1) found that the ouabain-sensitive and insensitive $\mathrm{Na}$ efflux was decreased by 5 and $35 \%$, respectively. With ethacrynic acid, he was able to further inhibit the ouabain-insensitive efflux by two-thirds. This ouabain-insensitive, ethacrynic acidsensitive $\mathrm{Na}$ efflux was diminished to about the same extent for homozygotes and heterozygotes, suggesting it to be useful in heterozygote detection. Lapey and Gardner (20) also observed a decrease in the ethacrynic acid-sensitive $\mathrm{Na}$ efflux except for homozygous young females and heterozygotes. Grinwald and Segal (12) found ouabain-insensitive $\mathrm{Na}$ efflux diminished in cystic fibrosis erythrocytes for $35 \%$. These findings could not be confirmed by Feig et al. (7) and Horton et al. (13) who found no abnormalities in the active $\mathrm{Na}$ and $\mathrm{K}$ transport in cystic fibrosis red blood cells.

The Na/K-ATPase was normal according to Feig et al. (7) and Katz (14). However, Balfe et al. (1) found in contrast to their transport data that only the ouabain-sensitive $\mathrm{Na} / \mathrm{K}$-ATPase in homozygotes was diminished by $32 \%$. Cole and Dirks (4) reported a significant decrease of $10 \%$ for the ouabain-insensitive $\mathrm{Na} / \mathrm{K}-\mathrm{ATP}$ ase but found no difference for the ouabain-sensitive component.

In spite of these conflicting data, it seems improbable that the active $\mathrm{Na} / \mathrm{K}$ transport in the cystic fibrosis erythrocyte is primarily impaired. Differences in medication and clinical situation of the patients, as well as slightly different experimental conditions may explain the variation in the results.

Furthermore, where divalent cation transport in the cystic fibrosis red blood cell is concerned, a normal Ca-ATPase activity was observed by Feig et al. (7) and McEvoy et al. (23). However, the latter found that the apparent affinity for calcium in cystic fibrosis was higher in contrast to Katz's finding of a $50 \%$ reduced activity of the Ca-ATPase with a normal affinity (14). A decreased enzyme activity corresponding to the severity of the pulmonary disease was reported by Horton et al. (13). According to Miner et al. (24), red blood cells from patients with cystic fibrosis have a reduced number of functional calcium pumps with a decreased affinity. The intracellular calcium level, however, is normal because the passive calcium permeability is also reduced. The Mg-ATPase activity was found to be normal by several workers $(13,14,23)$.

The findings summarized above do not permit one to draw a definitive conclusion about an alteration in cation transport of the red blood cells of patients with cystic fibrosis. The present study shows that the transport of mono- and divalent inorganic anions across the red cell membrane of patients with cystic fibrosis and controls is not significantly different. Secondly, we reconfirm that the polyacrylamide gel electrophoreses of the erythrocyte membrane proteins from patients with cystic fibrosis and healthy subjects show the same pattern $(8,23)$. So far, both morphological (33) and functional studies, including the transport studies presented above, suggest that the erythrocyte in cystic fibrosis is normal and therefore not a useful tool for the study of the pathogenesis of this disease.

Acknowledgments. We want to thank our blood donors and their parents for their cooperation in this project. We are indebted to Professor H. Passow for his comments on the manuscript and to Ms. A. Tintschl and Ms. M. Staebs for their technical assistance.

\section{REFERENCES}

1. Balfe JW, Cole C, Welf LG: 1968 Red cell transport defect in patients with cystic fibrosis and in their parents. Science 162:689

2. Bentley PJ, Christine McGahan M: 1982 A pharmacological analysis of chloride transport across the amphibian cornea. J Physiol 325:481

3. Brock CJ, Tanner MJA, Kempf C 1983 The human erythrocyte anion transport protein: partial amino acid sequence conformation and a possible molecular mechanism for anion exchange. Biochem J 213:577

4. Cole CH, Dirks JH: 1972 Changes in erythrocyte membrane ATPase in patients with cystic fibrosis of the pancreas. Pediatr Res 6:616

5. Dalmark M 1975 Chloride transport in human red cells. J Physiol (Lond) 250:39

6. di Sant'Agnese PA, Davis PB: 1976 Research in cystic fibrosis (3 parts). N Engl J Med 295:481,534,597

7. Feig SA, Segel GB, Kern KA, Osher AB, Schwartz RH: 1974 Erythrocyte transport function in cystic fibrosis. Pediatr Res 8:594

8. Fitzpatrick DF, Landon EJ, James V: 1972 Serum binding of calcium and the red cell membrane in cystic fibrosis. Nature New Biol 235:173

9. Funder J, Wieth JO: 1976 Chloride transport in human erythrocytes and ghosts: a quantitative comparison. J Physiol (Lond) 262:679

10. Gaskin KJ, Durie PR, Corey M, Wei P, Forstner GG: 1982 Evidence for a primary defect of pancreatic $\mathrm{HCO}_{3}{ }^{-}$secretion in cystic fibrosis. Pediatr Res 16:554

11. Grimes AJ: 1980 Human Red Cell Metabolism. Blackwell Scientific Publications, Oxford, pp. 92-93

12. Grinwald PM, Segal MB: 1978 Effect from saliva from cystic fibrosis patients and from normal subjects on red blood cell sodium transport. Pediatr Res 12:1

13. Horton CR, Cole WQ, Bader H: 1970 Depressed Ca transport ATPase in cystic fibrosis erythrocytes. Biochem Biophys Res Commun 40:505

14. Katz S: 1978 Calcium and sodium transport processes in patients with cystic fibrosis. I. A specific decrease in $\mathrm{Mg}^{2+}$ dependent, $\mathrm{Ca}^{2+}$ adenosine triphosphatase activity in erythrocyte membranes from cystic fibrosis patients Pediatr Res 12:1033

15. Kaul PK, Murthy SN, Reddy AG, Steck TL, Kohler H: 1983 Amino acid sequence of the $N^{\alpha}$-terminal 201 residues of human erythrocyte membrane band 3. J Biol Chem 258:7981

16. Kay MMB, Tracey CM, Goodman JR, Cone JC, Bassel PS: 1983 Polypeptides immunologically related to band 3 are present in nucleated somatic cells. Proc Natl Acad Sci USA 80:6882

17. Knauf PA: 1979 Erythrocyte anion exchange and the band 3 protein: transport kinetics and molecular structure. Curr Top Membr Transport 12:249

18. LaCelle PL: Effect of sphering on erythrocyte deformability. Biorheology 9:51

19. Langridge-Smith JE, Field M: 1981 Sulfate transport in rabbit ileum: characterization of the serosal border anion exchange process. J Membr Biol 63:207

20. Lapey A, Gardner JD: 1970 Abnormal erythrocyte sodium transport in cystic fibrosis. Pediatr Res 4:478

21. Levinson C: 1982 Chloride transport in the Ehrlich mouse ascites tumor cell In: Zadunaisky JA (ed) Choride Transport in Biological Membranes. Academic Press, New York, pp. 383-396

22. Mangos JA: 1978 Cystic fibrosis. In: Andreoli TE, Hoffman JF, Fanestil DD (eds) Physiology of Membrane Disorders. Plenum Press, New York, pp 941 953.

23. McEvoy FA, Davies RJ, Goodchild MC, Anderson CM: 1974 Erythrocyte membrane properties in cystic fibrosis. Clin. Chim. Acta 54:195

24. Miner C, Muallem S. Seymour CA: 1983 Characterization of the calcium pump in the red cells of patients with cystic fibrosis. J Physiol (Lond) 338:63P

25. Passow H. Fasold H. Jennings ML. Lepke S: 1982 The study of the anion transport protein ('band 3 protein') in the red cell membrane by means of tritiated 4,4' -diisothiocyanodihydrostilbene-2,2' -disulfonic acid ( $\left.3 \mathrm{H}_{2} \mathrm{DIDS}\right)$. In: Zadunaisky JA (ed) Chloride Transport in Biological Membranes. Academic Press, New York, pp 1-31

26. Quinton PM: 1981 Effects of some ion transport inhibitors on secretion and reabsorption in intact and perfused single human sweat glands. Pfluegers Arch. 391:309

27. Quinton PM: 1982 Suggestion of an abnormal anion exchange mechanism in sweat glands of cystic fibrosis patients. Pediatr Res 16:533

28. Quinton PM: 1983 Chloride impermeability in cystic fibrosis. Nature 301:42 I

29. Quinton PM, Bijman J: 1983 Higher bioelectric potentials due to decreased chloride absorption in the sweat glands of patients with cystic fibrosis. N Engl J Med 308:1185

30. Schwoch G, Passow H: Preparation and properties of human erythrocyte ghosts. Mol Cell Biochem 2:197

31. Steck TL: 1974 The organization of proteins in the human red blood cell membrane: a review. J Cell Biol 62:1

32. Talamo CT, Rosenstein BJ, Berninger RW: 1983 Cystic fibrosis. In: Stanbury JB, Wyngaarden JB, Fredrickson DS, Goldstein JL, Brown MS (eds) The Metabolic Basis of Inherited Disease. McGraw-Hill, New York, pp 1889 1920

33. Warwick WJ, Hansen LG, Shapiro BG: 1982 Erythrocyte indices in cystic fibrosis. Am J Med Techn 48:539

34. Westerman MP, Pierce LE, Jensen WN: 1961 A direct method for the quantitative measurement of red cell dimensions. J Lab Chem Med 57:819

35. Wieth JO, Andersen OS, Brahm J, Bjerrum PJ, Borders CL Jr (1982) Chloridebicarbonate exchange in red blood cells: physiology of transport and chemical modification of binding sites. Phil Trans R Soc Lond B299:383 